\title{
Comparative Analysis of Organizational Structure and Operations of Modern and Traditional Cooperatives on Mobilization of Savings in South-East, Nigeria
}

\author{
F. E. Ebe \\ Department of Agricultural Economics, Michael Okpara University of Agriculture, Umudike, Abia State, \\ Nigeria.
}

\begin{abstract}
The primary concern of this study is to compare and analyze structure and operations of indigenous and modern cooperatives in mobilizing savings in South-East, Nigeria. The study examined and compared the socio-economic variables of the members of the cooperatives, nature, objectives and structures of the two forms of the cooperatives. The study covered 36 cooperatives out of which were 18 modern and 18 traditional. These cooperatives were selected from 6 agricultural zones of Ebonyi and Enugu States. Thirty six leaders of the association were purposively selected and 180 members of the cooperatives were sampled in both formal and informal associations. Primary data were collected through the use of questionnaire designed differently for the leaders and members of both forms of the cooperatives. The data were analyzed using percentage and chi-square $\left(X^{2}\right)$ test. The findings of the study revealed that both forms of cooperatives operate savings mobilization under non-rotating and only indigenous operate rotating savings. The result showed that majority of the co operators was literate and married. The study showed that average ages of the associations were 8.9 and 7.9 years for the indigenous and modern cooperatives respectively. Both forms of association differed in their membership strength and informal group having an average of 52 and formal group 46. The organizational structure showed that the officials of the associations included president, secretary, treasurer and provost. Good character was considered most in the selection or election of these officers. The objectives of both associations centered on the promotion of the welfare and economic development of the members. Test of significance showed that both cooperatives did not differ significantly $\left(X^{2}\right.$-cal was 10.38 while $X^{2}$-tab was 12.5). The associations focused on maintenance of law and order within their group and on fund mobilization for community development in their operations. The two forms of cooperative did not differ significantly with $X^{2}$-cal being 7.4 and $X^{2}$-tab 12.2. In conclusion, the study has shown that both associations had similarities in their nature, structure and operations in mobilizing savings, therefore sound policy measure should be taken so as to give formal recognition to indigenous cooperatives by government because these associations have a lot of potentials that made the indigenes have more confidence on them.
\end{abstract}

Keywords: Economic development, Agricultural economics and indigenous cooperatives.

\section{Introduction}

Investment in physical and human capital must be matched by savings either from domestic sources or from aboard. If growth is to be sustained and self-generating most of the savings will come from domestic savings [1]. Saving is income refrained from spending or not spent on goods and services for consumption [2]. Savings are made either in cash or kind. These days savings in cash is what is obtained in most areas and associations. The savings are mobilized from the members of the association which could be either modern or traditional groups. The members of the group use the association as media to pull their resources together where it could be channeled to a useful purpose. One of the associations that play such role effectively is cooperative society. These cooperatives in most cases encourage the members to save even small amounts regularly which otherwise would have been spent on consumption.

Cooperatives among the rural masses could be formal or informal. The formal/modern cooperative is the type that took its roots on the British "Society of equitable pioneers" founded in Rochdale in 1844 which is based on imported or transplanted western culture - individualism, liberalism, rationalism, capitalism and democracy [3]. The informal/traditional cooperation is described as those groups which do not trace their origins to the Rochdale, Raiffeison, Schulze-Delitzech principles, but have existed even before the introduction of modern or imported forms of cooperatives [4]. These cooperatives are made up of people of the same lineage, a committee of friends, men and women groups belonging to some age grade or bracket, etc, for the purpose of fostering unity, progress and cooperation. Whether an association is classified as formal or informal, traditional or modern, the basic principle concerning both is that they are set up to find solutions to some basic problems concerning the core participants as they are sufficiently flexible to respond in distinct ways to different socioeconomic environment. 
For the associations to perform creditably well on the aspect of mobilizing the members saving and directing it into desirable viable economic investment depends largely on how they are organized, coordinated and the mode of their operations. The organizational structure of the associations also determines how effective the organization is administered. They could be organized along the line of their economic activities, sexes and religion affiliation. These enable them to evolve, diversify and consolidate on their economic and social activities.

In order to ensure that cooperatives are well and properly functioning government assist them especially the modern cooperatives through capacity building, delivery of inputs, offer of credit, organization of seminar/workshop etc, for the members. These assistances are offered to the modern cooperatives leaving traditional cooperatives. The problem here arises that despite the vital functions the informal associations play in rural areas, government has not given proper and adequate recognition to these cooperatives. With the neglect of the informal cooperatives by government and its support of the modern cooperatives, it becomes imperative to address the issue pertaining to the organizational structure and operations of these cooperatives with regards to mobilization of fund in rural areas by answering the following question. Are there differences in the organizational structure and operations of modern cooperatives as a result of government involvement relative to traditional groups?

The study therefore examined the socio-economic characteristics of the members of two forms of the groups. It also identified and compared the nature, objectives and structure of both forms of the cooperatives. Finally, it compared the operations of modern and traditional cooperatives.

\section{Methodology}

South-East of Nigeria was purposely selected for this study because the zone has many cooperative societies. The zone is a progressive zone from cooperative point of view. There are various kinds of cooperatives in the zone which are not common in other zones except in Igbo states.

In order to have a good spread of the respondents in the zone, random sampling techniques were used. From the south-east zone that was used for the study, two states were randomly selected, namely Ebonyi and Enugu states. The two states chosen were made up of six agricultural zones - Ebonyi North, Central and South, Enugu East, West and North. From each of the agricultural zone, one Local government area was randomly selected (these were Ishielu in Ebonyi Central, Ohaukwu, Ebonyi North, and Ivo in Ebonyi South, Isi-uzo Enugu East, Udi Enugu West and Igbo-Etiti in Enugu North).

From the LGAs selected, three communities were randomly chosen making it 18 communities that were used for the study. Then from each community of 18 communities chosen, two cooperatives were randomly selected, one modern and the other traditional. This gave a total of 18 modern and 18 traditional cooperatives, making it a grand total of 36 cooperatives used in the study area.

For the formal cooperatives in each of the local government drawn, a list/register of the communities and the registered cooperatives was made available by the cooperative officer in charge and from there the random selection was made. For the informal association in each of the communities chosen, traditional cooperatives/groups were randomly drawn from the frame compiled by the secretaries or the village heads of these communities.

In each of the 36 associations, the group leader was purposively selected and with his/her aid, five active members of the societies were randomly drawn from each group. This brought the sample size to 180 respondents and the leaders of the cooperatives selected.

Data were obtained through primary sources. Two sets of questionnaires were designed, one for the leaders of the cooperatives and the other for the members of the association. Data obtained from the leaders included origin, and nature of the associations, organizational structure, membership and operations of the cooperatives. The information obtained from the members included socio-economic characteristics. Also "focus group" discussion was applied. This technique enabled the respondents to express their views on the research [4].

The data were analyzed by using description statistics such as percentage. Chi-square $\left(\mathrm{X}^{2}\right)$ statistics was applied to see if such variables as objectives and operations of the indigenous cooperatives on one hand and modern cooperatives on the other differed significantly.

The formula used is shown below

$X^{2}=\sum \frac{(O-E)^{2}}{E}$

Where

$\sum=$ summation (sign for adding up)

$\mathrm{O}=$ observed frequency

$\mathrm{E}=$ corresponding expected frequency

Chi-square calculated is significant at a given $\alpha$-level if $X^{2}$-cal is greater than $X^{2}$-tab. 


\section{Typology}

\section{Results And Discussion}

\section{Traditional Associations}

In the study area, there are different types of indigenous cooperatives. They are organized along the line of their economic activities, sexes and religious affiliation. The associations go by different names such as age grades, youth association, committee of friends etc, but they are basically grouped under rotating and non- rotating savings association.

Rotating Savings Association: This is the type of association members contribute money on agreed basis and the mobilized savings are handed over to one of the members at subsequent meetings. The meetings are usually held weekly, fortnightly or monthly. Out of the 18 traditional cooperatives studied, $55.6 \%$ of the associations were grouped under the category.

Non-rotating Savings Association: This is the one in which savings are mobilized from the members of the association and the money is kept with the treasurer or banked in a situation where the association operates an account. At the end of the session, part of the money is shared among the members according to the contributions made by each while part of the amount is kept in the associations account for investment in other ventures. In all the indigenous associations studied, $44.4 \%$ were classified under nonrotating savings association.

\section{Modern Cooperatives}

The type of modern cooperatives studied is classified under farmers' cooperative society. The cooperatives employed savings mobilization as self-help techniques for the social and economic benefits of the members. The savings mobilization is carried out through collective investment in agricultural ventures which centered on the production of crops. Marketing of such crops forms an integral part of the cooperatives' economic activities. All the modern cooperatives studied mobilized savings by collection of members' savings (cash) in form of thrift at a pre-arranged period which is often on monthly basis. This form of savings scheme is largely carried out on non-rotating basis.

\section{Socio-Economic Characteristics of Members}

Table 1: Percentage distribution of respondents according to their socio-economic characteristics

\begin{tabular}{|c|c|c|}
\hline Variables & $\begin{array}{l}\text { Percentage for indigenous cooperatives. } \\
\mathrm{N}=90\end{array}$ & $\begin{array}{l}\text { Percentage for modern } \\
\text { cooperative. } \mathrm{N}=90\end{array}$ \\
\hline \multicolumn{3}{|c|}{ Age } \\
\hline $21-30$ years & 11.1 & 2.2 \\
\hline $31-40$ years & 38.9 & 32.2 \\
\hline $41-50$ years & 28.9 & 50.0 \\
\hline 51 and above years & 21.1 & 15.6 \\
\hline \multicolumn{3}{|c|}{ Education } \\
\hline No formal education & 22.2 & 8.9 \\
\hline Attended primary school & 45.6 & 48.9 \\
\hline Attended secondary school & 22.0 & 31.1 \\
\hline Attended beyond secondary school & 10.0 & 11.1 \\
\hline \multicolumn{3}{|c|}{ Economic activity } \\
\hline Farming & 38.9 & 35.6 \\
\hline Civil service & 12.2 & 18.9 \\
\hline Teaching & 17.8 & 23.3 \\
\hline Artisan & 11.1 & 10.0 \\
\hline Petty trading & 20.0 & 12.2 \\
\hline \multicolumn{3}{|c|}{ Marital Status } \\
\hline Single & 18.9 & 6.7 \\
\hline Married & 72.2 & 80.0 \\
\hline Widowed & 6.7 & 10.0 \\
\hline Divorced & 2.2 & 3.3 \\
\hline
\end{tabular}

From the table 1 shown above, the result showed that the distribution of the cooperators with regards to age revealed that there was high proportion of middle aged group ( $31-50$ years) in both forms of the association as traditional association recorded $67.8 \%$ while that of modern group was $82.2 \%$ respectively. This showed that belonging to the associations would enable them to be committed and save more, otherwise the money would be spent on conspicuous consumption. The table showed that younger and older people participated more in traditional groups as they had $11.1 \%$ and $21.1 \%$ informal groups as against $2.2 \%$ and $15.6 \%$ in formal group respectively. The reason given was that entry into traditional group does not need much protocol.

Also majority of the cooperators had formal education $(91.1 \%$ in modern and $77.6 \%$ in traditional groups, respectively). The high percentage of education was that some of the retirees and retrenched civil 
servants had settled in their different homes and take part in various activities.

On the economic activities, $38.9 \%$ of the cooperators were farmers in traditional group while $35.6 \%$ were in same profession in modern cooperative. The high proportions of farmers recorded when compared with other professions suggest that agriculture is still the core economic activity of the rural dwellers.

On the other hand, $20 \%$ of petty traders participated more in the traditional groups relative to $12.2 \%$ obtained in modern cooperatives. The greater number of the petty traders in informal group was attributed to the fact that savings mobilized are usually shared in the months of November/December when money realized by the members are invested in their business to take advantage of the Christmas period when the volume of sales is high.

With regards to marital status, the study showed that majority of cooperators were married with $72.2 \%$ in informal and $80 \%$ in formal associations while divorced ranked least (2.2\% in informal and 3.3\% in formal associations). This shows that marriage is highly honoured in the rural society and divorce discouraged. Age and Membership of the Associations

The age and membership strengths of the associations were studied and the results are shown in tables II and III below.

Table I: Percentage distribution of the associations according to years of formation

\begin{tabular}{|l|l|l|}
\hline Number of years & $\begin{array}{l}\text { Percentage for Traditional } \\
\text { Cooperative. } \mathbf{N}=\mathbf{1 8}\end{array}$ & $\begin{array}{l}\text { Percentage for Modern } \\
\text { Cooperatives. } \mathbf{N}=\mathbf{1 8}\end{array}$ \\
\hline $1-5$ & 38.9 & 5.6 \\
\hline $6-10$ & 16.7 & 27.8 \\
\hline $11-15$ & 22.2 & 44.4 \\
\hline $16-20$ & 5.6 & 11.1 \\
\hline $21-25$ & 11.1 & 11.1 \\
\hline 26 and above & 5.6 & - \\
\hline
\end{tabular}

Table III: Membership strength of the association
\begin{tabular}{|l|l|l|}
\hline Size & Traditional association & Modern association \\
\hline $1-20$ & 4 & 0 \\
\hline $21-40$ & 6 & 7 \\
\hline $41-60$ & 2 & 4 \\
\hline $61-80$ & 2 & 3 \\
\hline $81-100$ & 1 & 1 \\
\hline $101-120$ & 1 & 1 \\
\hline $121-140$ & 1 & 2 \\
\hline 141 and above & 1 & 0 \\
\hline
\end{tabular}

The above table II showed the age of the associations. It depicted that the mean age of the traditional cooperatives was 8.9 while that of modern associations was 7.6 years. The table showed that $5.6 \%$ of the traditional association fell within the age of 26 years and above while none was recorded in modern association. The survey showed that traditional association had the oldest organization (28years for indigenous and 25 years for modern cooperatives). However, it further showed that the two associations differed in age. This supports the view that self-help groups based on saving thrive long perhaps because of the absence of government intervention. With long years of existence, the association would be able to diversify and consolidate on its economic and social activities.

Table III showed the membership per group. The total membership per group ranged from $13-154$ members in indigenous and $23-126$ members in modern groups. The average membership strength for the informal associations was 52 and 46 for modern group. The above findings showed that the two forms of the organizations differed in their membership strength with traditional organization having more members per group. This result has gone to confirm the result of table II which showed traditional associations to have existed for many years, indicating that members of traditional groups are closely tied to their immediate family or clan, they support local union (club) and they take pride in their local achievements.

\section{Organizational Structure}

The organizational structure of any association help to determine the effectiveness of the group as this involves the grouping of the members inform of post with duties or delegation of authority to each post so that the work of the association is carried out as planned, this depends largely on the leadership of the association. 


\section{Leadership and its Qualities}

In the two types of cooperatives studied, traditional associations had leaders whose number ranged from 3-7 with an average number of 5 committee while in modern groups the number of officials ranged from 7- 11 with an average number of 6 executive members.

The basic hierarchy of authority (executive committee) of the associations consisted of president/chairperson, secretary, treasurer and provost. In addition there was the post of public relation officer (PRO). This office was more pronounced in modern cooperatives than traditional group. Different functions were assigned to the officials and they collectively were responsible for the smooth running of the organizations. They maintain discipline, authority and provide initiatives for the efficient operations of the cooperatives.

In the two forms of the associations, membership of the executive committee was based on election or appointment. One hundred percent of modern cooperation select their officers by election while $61.9 \%$ by appointment. The appointment or election of the leaders takes place during their general meetings through consensus or unanimous decisions.

The tenure of the officers varies from two to four years. In the selection or appointments of the executive committee, the following criteria were considered in carrying it out as shown in table IV.

Table IV: Distribution of the association according to criteria for selecting the executives.

\begin{tabular}{|l|l|l|}
\hline Criteria & Percentage for Indigenous Association & Percentage for Modern Association \\
\hline & $\mathrm{n}=18$ & $\mathrm{n}=28$ \\
\hline Good character & 100 & 100 \\
\hline Literacy advantage & 27.8 & 44.4 \\
\hline Age and experience & 44.4 & 66.7 \\
\hline Formation pioneering advantage & 11.1 & 5.6 \\
\hline Leadership is rotator & 16.7 & 16.7 \\
\hline Wealth advantage & 5.6 & - \\
\hline
\end{tabular}

Multiple responses recorded.

Table IV showed that hundred percent was recorded on good character in both forms of the associations. This implies that in rural areas, good behaviour is considered most in any dealings with fellow human being. Also age and experience matter in the two types of the cooperatives. This bring into bear that these associations are piloted in the way it is supposed to be. Modern cooperatives rated literacy advantage high (44.4) compared to $27.8 \%$ that was recorded in indigenous group. These findings agreed with Oladeji (1979) [3] who noted that the executives of the modern cooperatives must be literate and also functionally educative in art of cooperative business operations and rules governing their societies.

\section{Objectives of the associations}

Table V: Distribution of the associations based on their objectives

\begin{tabular}{|l|l|l|}
\hline Objectives & $\begin{array}{l}\text { Information Association } \\
\text { Percentage n= 18 }\end{array}$ & $\begin{array}{l}\text { Formal Association } \\
\text { Percentage n= 18 }\end{array}$ \\
\hline Assist members in time of financial crisis & 88.0 & 83.3 \\
\hline Financial help to members' business & 11.1 & 22.2 \\
\hline Group investment in agricultural ventures & 44.4 & 88.9 \\
\hline $\begin{array}{l}\text { Fund mobilization for community } \\
\text { development }\end{array}$ & 50.0 & 22.2 \\
\hline Employment generation & - & 5.6 \\
\hline Welfare scheme for members & 94.4 & 88.3 \\
\hline $\begin{array}{l}\text { Group investment in other economic } \\
\text { activities }\end{array}$ & 77.8 & 27.8 \\
\hline
\end{tabular}

Multiple responses recorded

Table V shows that modern cooperative excelled in group agricultural investment with $88.9 \%$ compared to $44.4 \%$ recorded in traditional group. The reason adduced was that it is an avenue for the modern group to attract government assistance either in form of loan or farm inputs. Fifty percent of the indigenous association focused their goal on fund mobilized for community development relative to $22.2 \%$ of the modern group that tackle this as their objective. The above result confirms the view that some traditional associations set aside group fund for use in joint development efforts of the community in which they operate.

Employment generation ranked least in the objective of both association with 5.6\% in modern and none in traditional associations.

This finding reflects the view that the impact of cooperatives on employment is limited when compared with other economic sector. A test of difference in the objectives of the two associations was applied by using chi-square $\left(\mathrm{X}^{2}\right)$ statistic. The result showed that there was no significant difference between the objectives of

the two forms of the cooperatives as $\mathrm{X}^{2}$ - cal was 10.38 and $\mathrm{X}^{2}$ - tab 12.59 at $5 \%$ level of significance. Hence the non difference in the objectives of the two forms of cooperatives points to the facts that the pre-

occupation of all the associations studied centered on the economic and social interest of the members through self-help. Operations of the Associations 
Based on the objectives of the cooperatives, the functions of the associations were examined and the responses of the respondents are shown in table VI below.

Table VI: Distributions according to the functions of the associations.

\begin{tabular}{|l|l|l|}
\hline Operations & $\begin{array}{l}\text { indigenous Association } \\
\text { Percentage n= 18 }\end{array}$ & $\begin{array}{l}\text { Modern Association } \\
\text { Percentage n = 18 }\end{array}$ \\
\hline $\begin{array}{l}\text { Maintain progress, peace and harmony } \\
\text { within the group }\end{array}$ & 100 & 100 \\
\hline $\begin{array}{l}\text { Assist in organization and supervision of } \\
\text { members social activities }\end{array}$ & 77.8 & 44.4 \\
\hline Mobilize fund for social activities & 72.2 & 55.6 \\
\hline $\begin{array}{l}\text { Assist community leaders to maintain law } \\
\text { and order }\end{array}$ & 50.0 & 24.8 \\
\hline $\begin{array}{l}\text { Contract labour for farm work for the } \\
\text { members and non-members }\end{array}$ & 22.2 & 5.6 \\
\hline $\begin{array}{l}\text { Raise fund for community development } \\
\text { projects }\end{array}$ & 61.1 & 16.7 \\
\hline $\begin{array}{l}\text { Create awareness on government polices and } \\
\text { pass information on improved farm } \\
\text { practices }\end{array}$ & 66.7 & 88.9 \\
$\mathrm{X}^{2}-$ cal 7.4 X ${ }^{2}-$ tab 12.5 \\
$\begin{array}{l}\text { Multiple responses recorded } \\
\text { VI }\end{array}$
\end{tabular}

Table VI showed that the entire associations play vital role in the maintenance of peace and harmony within the group as $100 \%$ was recorded in the two different groups. This implies that this function ensures the smooth running of the organizations. The table also showed that majority of the associations $(66.7 \%$ informal and $88.9 \%$ informal groups) assist in the dissemination of information on farming practices among their members and equally creates awareness on government policies. This suggests that these associations act as useful media for agricultural extension agents to reach many farm families in the rural areas.

A test of significance difference was carried out on the operations of the associations. The result showed that there was no significant difference in the operations of the two forms of the group as $\mathrm{X}^{2}-$ cal was 7.4 and $\mathrm{X}^{2}-$ tab 12.5. This implies that both associations share similar activities in spite of slight differences in their objectives and principles. This indicates that cooperatives either traditional or modern centre their activities on social and economic benefits of their members and the communities of their operations.

\section{Conclusion}

The study showed that both forms of the associations operate savings mobilization under non-rotating savings and only indigenous groups operate rotating savings. The result of the study showed that majority of the cooperators was literate and married. It further showed that the two associations were predominated by farmers, government employees and petty traders.

The study also showed that the average ages of the associations were 8.9 and 7.9 years for indigenous and modern cooperatives respectively. The findings showed that the forms of the organizations differed in their membership strength with traditional organizations having more members per group as it indicated that the average membership of informal association was 52 while that of formal ones was 46.

The organizational structure of both forms of the cooperatives showed that officers of the associations included president, secretary, treasurer and provost. In the selection or election criteria of the officers, good character is considered most before the person is appointed or elected.

The main objectives of both associations centred on the promotion of the welfare and economic development of the members. The test of difference showed that both cooperatives did not differ significantly $\left(\mathrm{X}^{2}-\right.$ cal was 10.38 while $\mathrm{X}^{2}-$ tab was 12.5$)$. In the operations of the associations, it showed that the associations focused on maintenance of law and order within the group and also on fund mobilization for community development. The result of the test of significance between the two associations showed that they were statistically non-significant with values of $X^{2}-$ cal being 7.4 and $X^{2}-\operatorname{tab} 12.2$

In conclusion, the survey has shown that both associations had similarities in their nature, structure, and operations in saving mobilizations. This adequate and sound police measures should be taken so as to give formal recognition and solid backings to indigenous associations as government did to modern cooperatives. This involves preparation of bye-laws, formal registration of the associations and upgrading them so that they 
could enjoy equal levels of remunerations as it applies to modern cooperatives. This is because with legal backings to these societies, many rural dwellers who participated more in the informal groups stand to benefit more as they have more confidence on traditional cooperatives than the modern types.

\section{References}

[1]. Fujisawa, K. (1974). "Discrepancy Between the Principles of Modern Cooperation and those of Traditional Rural Life". Year Book of Agricultural Cooperation. London: The Plunket Foundation for cooperative Studies.

[2]. Lipsey, R.G. (1983). An Introduction to Positive Economics. London: Butter and Tanner.

[3]. Nweze, N. J. (1990). The Structure, functioning and potentials of indigenous cooperatives credit associations in Financing Agriculture. A case study of Anambra and Benue States, Nigeria. An unpublished Ph.D Thesis Department of Agricultural Economics, University of Nigeria, Nsukka.

[4]. Oladeji, M.O. (1979). "An Approach to Cooperative Member Education Through functional Literancy: Oyo State Experience Paper Presented at the National Conference on Cooperatives in the $4^{\text {th }}$ National Development Plan of Nigeria 1981-85, U.N.N, September, 1979.

[5]. Waler, R. (1985). Applied Qualitative Research Hants: Grower Publishing Company. 